\title{
The Effectiveness of Differentiated Instruction by Streaming: A preliminary Study of Current Practices in the UAE
}

\author{
Ibrahim Suleiman Ibrahim Magableh \\ USM, Universiti Sains Malaysia-Malaysia \\ USM, Gelugor, Penang 11800 -Malaysia \\ https://orcid.org/0000-0001-5983-7145 \\ Amelia Abdullah \\ USM, Universiti Sains Malaysia-Malaysia \\ USM, Gelugor, Penang 11800 -Malaysia \\ https://orcid.org/0000-0002-4055-699X
}

\begin{abstract}
Differentiated instruction is modifying teaching to suit one, small group, or all learners. There are two ways to classify students into differentiated classes. The first one is grouping students by mixed-ability schoolrooms, and the other is to split by streaming. This qualitative exploratory study explored the advantages and challenges of differentiated instruction by streaming in the UAE. The authors aim to search the benefits and disadvantages of streaming in the UAE context because the UAE applied splitting instead of mixed-ability classrooms. Twelve cycle two English teachers, and 20 cycle two EFL students, from four different schools, which are applying differentiated instruction by streaming, participated in a semi-structured interview to answer the questions of the study based on a convenience sampling. The study indicated that streaming helps all students' proficiency levels. The above-average students benefit the most from streaming, and some profound benefits were suggested for the below-average students. The most apparent advantages were having equal opportunity for participation among all the three levels, having better achievement grades, and the increase of independent learning. However, the disadvantages suggested by the respondents were the use of native language, classroom interruption, having negative behavioral issues, and labeling the below-average as weak students.
\end{abstract}

Keywords: differentiation; streaming; mixed-ability classroom; differentiated instruction 


\section{Introduction}

The one-size-fits-all method is no longer acceptable in today's classrooms (Bondie, Dahnke \& Zusho, 2019). Today's classrooms vary in readiness, interests, learning profile, family support, culture, socio-economic status, and the technology that students use. Classroom diversity leads many researchers (Tomlinson \& Imbeau, 2010) to call for different trends in education and explicitly call for differentiated instruction to solve the problem of various classroom levels. Tomlinson (2017) defines differentiated learning as the adaptation of curriculum components, in the areas of content, process, and product, based on students' needs according to their readiness, interests, and learning profiles by the teachers in their classes whenever they want, during the whole course, small groups or individual learners. Wesley-Nero (2007) explains that in differentiated classrooms, teachers work to highlight students' learning styles and academic needs by using various modified instructional structures like the use of small groups, pairs, individual and whole group education. Teachers modify the content they are dealing with and the learning process they are following to present the content and the expected outcome to fulfill the best students' needs (Aysin \& Serap, 2017).

In modified instruction, teachers vary their teaching to suit whole learners, small groups, pairs, or individual learners, in the areas of content, methods, product and learning environment based on students' readiness, interests and learning profiles. Tomlinson (2014) explains the definition of each area. The content is the knowledge, understanding, the principles, and the values that we want students to learn. The content is what students learn and what teachers teach. Differentiating the content does not mean having different content to various learners or change the content itself; instead, teachers sometimes need to go back to prerequisite content or go forward to specific students.

The process is the way students learn or the way the teachers teach. Tomlinson states that the word "process" is another word for "activities." According to Tomlinson (2014), processes and activities are two terms referring to one thing; the way the students learn, and the way the teacher teaches. The product is how students demonstrate what they have come to know, understand, and able to do after an extended period of learning. The product is what students show after they have learned something. Teachers distinguish the product by giving students various ways to express what they have studied from the lesson or unit (Anderson, 2007). The environment is the place and the atmosphere of learning and teaching, and it is the physical and emotional context in which learning occurs. Readiness is the students' proximity to knowledge, understanding, and skills; it is the previous knowledge, not the ability (Pegram, 2019). Tomlinson stated that willingness does not mean ability because it can change with the quality of teaching. Interest is tied directly to that which engages the attention, curiosity, and students' involvement. Learning profile is a preference for taking in, exploring, and expressing content.

Although distinguished learning is not a new approach in teaching, many teachers are still adopting the traditional approach like the one-size-fits-all 
method, all learners studied following the same means of training for all students (Leblebicier, 2020). Planning for separated education would be the most challenging part of differentiated instruction, which might lead many teachers not to implement modified instruction in classrooms (Bondie, Dahnke \& Zusho, 2019; Magableh \& Abdullah, 2020b). Teachers can execute distinguished instruction in two forms: the first is distinguished learning by setting students in mixed-ability classes; students of the same grade are clustered within the same classroom. Therefore, teachers have to meet all students' needs and abilities and modify instruction in the areas of content, process, and product at the same time to suit a small group of learners, one learner or all learners. The second type of differentiated learning is streaming by ability, where each level is disconnected in different classrooms (Spina, 2019). The below-average, the average, and the above-average students are not reading in the same classes; instead, they are being clustered in different ability classrooms (Hallam \& Parson, 2013). There are many advantages when differentiated learning is applied. Students become engaged, interaction increases, classes become more homogeneous and students become responsible of their own learning.

\section{Literature Review}

\subsection{Theories of Differentiated Instruction}

Differentiated instruction is not a new term or a modern philosophy (Anderson, 2007; Kauchak, 2013; Valiandes \& Neophytou, 2018). Anderson (2007) states that it goes back to the one house schoolroom, where all students with different levels used to sit all together, and teachers used to teach and differentiate instruction based on their needs. Distinguished learning is constructed on many theories like Vygotsky's Zone of Proximal Development (ZPD), Bloom's Taxonomy, and Gardner' Multiple Intelligences (Dendup \& Onthanee, 2020). Vygotsky's ZPD is the distance between what students can do and what they can do with the help of an adult. In differentiated education, teachers provide challenging activities to each level, to the below-average, to average, and to the above-average (Magableh \& Abdullah, 2019, Magableh \& Abdullah, 2020b). The below-average students would not find the offered tasks too complicated, which might lead them to quit. The above-average students would not see the given responsibilities too easy that might lead them to feel unchallenged and disappointed (Anstee, 2014).

In Blooms' Taxonomy, teachers have to plan and design activities to meet students' proficiency levels. Teachers have to make tiered activities from various levels of Bloom's Taxonomy to fulfill students' levels. There are six levels in Bloom's Taxonomy; the lower three levels are remembering, understanding, and applying; the upper three are analyzing, evaluating, and creating (Magableh \& Abdullah, 2020a). Teachers can prepare activities from recognizing and understanding levels to below-average students, applying and analyzing levels to ordinary students, and evaluating and creating standards to meet the aboveaverage students (Weselby, 2014). According to Gardner (2018), students learn in different styles or "bits of intelligence." Gardner identified eight bits of intelligence. The eight bits of styles, as Gardner identifies, are the visual or the spatial, interpersonal, intrapersonal, kinesthetic, logical or mathematical, 
musical, linguistic, and natural. Teachers in differentiated direction have to know their learners' preference style of learning and distinguish instruction based on students' learning profiles (Kotob \& Abadi, 2019; Magableh \& Abdullah 2020b). These three learning theories, Vygotsky's ZPD, Bloom's Taxonomy, and Gardner's Multiple Intelligences, form the foundations of differentiated instruction.

\subsection{Differentiated Instruction by Streaming}

Differentiated instruction is not a method of teaching; instead, it is a philosophy and takes many forms of strategies (Tomlinson, 2015). Separated education is a must and a need in today's classrooms. But whether to differentiate instruction in mixed-ability classrooms or to stream them by ability is still debatable (Mansor, Maniam, Hunt \& Nor, 2016). Streaming means grouping students based on their proficiency level in separate classes (Kumar, 2004; Macqueen, 2008). School administrations differentiate students by streaming by taking the last years' summative results to place students in three levels, or apply a placement test at the beginning of the year. Based on the results, students separate. The below-average, the average, and above-average students are disconnected into three different levels at the beginning of the year in three separate levels, where each group forms a different class (Sisk, 2019). Differentiated learning teachers delivered instruction using three different textbooks that suit the students' levels. Students at the same level are homogenous in proficiency and stay in this group till the end of the school year. The below-average is taught necessary skills following the low-level outcomes of Bloom's Taxonomy of remembering and understanding. The ordinary students are prepared following the middle level of Bloom's Taxonomy of applying and analyzing. In contrast, the above-average uses the upper level of Bloom's Taxonomy of evaluation and creation.

The setting puts putting students in mixed-ability classrooms, where all students are in one classroom despite their diversity and ability (Westwood, 2018). In mixed-ability classrooms, teachers distinguish instruction to the whole class, small group, pairs, and individual learners at the same time at the same level based on readiness, interests, and learning profile (Robb, 2008). However, in streaming categories, students are separated in different levels and instructed a diverse curriculum, and probably by different teachers. Hallam and Parson (2013) examined streaming effects on students compared to setting students into mixed-ability classrooms on both literacy and Math. There were 2500 students participated in the study, which indicated that streaming had many adverse effects on students compared to those who were sitting in mixed-ability classrooms. The study stated that the use of streaming helped the high-ability students the most, but it has minimal benefits on average or below-average students. Besides, the study showed that streaming has adverse social effects on students that the mixed-ability classrooms do not have. Richard (2014) indicated that based on the findings of the study, streaming in London had faced many criticisms by parents and many school teachers as well as students; therefore, the government directed to cancel it and apply distinguished education by setting students in mixed-ability classrooms instead. 
Mansor, Maniam, Hunt, and Nor (2016) explored the advantages and disadvantages of streaming in Malaysia from students' and teachers' perspectives. The authors conducted semi-structured interviews with teachers and students to collect data. The study revealed that streaming has many advantages, like the above-average can achieve more when they are in separate classes, and they are getting A's anyway. The teachers expressed that streaming helped them get better results with both: the low-level and the high-level students. However, many disadvantages appeared, like many complaints from fathers and students like the below-average students' needs were not taken into consideration. The interviewees indicated that streaming helps the aboveaverage students, but not the below-average ones.

The literature of both differentiated instruction by streaming students, or by setting them in mixed-ability groups, proved to enhance learning. On whether to stream students by ability in which different grade levels are separated into different classes, or to put them into mixed-ability classrooms, where all students of the same grade level are learning together in the same courses is one primary aim of the study. The UAE started the streaming project in 2018. All public cycle two schools have to stream students by ability, and divide them into three levels into separate classes instead of setting them in one mixed-ability classroom. The below-average students are called literacy students and study Literacy books based on the low level of Bloom's Taxonomy. The average students are called access and read Bridge to Success, Access Level, which mainly matches the middle level of Bloom's Taxonomy of synthesis and application. However, the above-average students were studying Bridge to Success and named the elite students. All the exams of all levels are also distinguished, whether the ongoing assessments or summative assessments. Each level has a separate and different review. The current study tries to explore the advantages and disadvantages of this new method of classifying students in the UAE. This study will be different than other studies because it is exploring a new trend in separated learning in this country. Here, there are many opinions about the benefits of this new implementation of this kind of differentiated instruction, so this study aims to find the benefits and disadvantages of applying streaming in the UAE. The study tries to answer the following two questions:

$1 /$ What are the benefits of using streaming to differentiate instruction?

$2 /$ What are the disadvantages of streaming to differentiate instruction?

\section{Methods}

\subsection{Design}

The researchers followed the qualitative exploratory quasi-experimental design. The instruments consisted of two semi-structured interviews with both English teachers and students who were in cycle two in Al Ain schools, United Arab Emirates (UAE). The authors prepared the interview questions and validated them by a panel of two UAE university lecturers, two English supervisors in Al Ain, and three English teachers. The latter were outside the sample of the study. Amendments were made on particular questions of the interview based on the 
recommendation of the panel. Later, after the meetings, the researchers discussed the results with the interviewees for results validity.

\subsection{Participants}

The sample of the study consisted of 12 English teachers based on a voluntary and convenient sample and aging from 26 to 50 years old from both genders teaching grade 8 and of 18 students of both sexes aging from 13 to 14 years old, purposively selected from the three leveled classes of categories eight. The students were chosen from four different public schools in Al Ain, UAE, which are applying streaming in them. They were purposefully selected for convenience to reach and conduct the interviews. There were 22 classes of grade eight in the four schools and 12 English teachers teaching them. As an average, types of grade 8 range between 25 to 28 students. There were six above-average classes, eight ordinary levels, and eight below-average courses. All the English teachers of grade eight, in the four schools, agreed to participate in a semistructured interview, and they were only 12 teachers in the 1st semester 2019/2020. The researchers interviewed the 12 teachers first and then interviewed the 18 students, six students of each level, two from each gender. The researchers followed the interview protocol to ask the questions of the interview, and they recorded the interviewees' responses after gaining the consent of the school administrations, teachers as well as students.

\subsection{Instrument}

Two semi-structured interviews were conducted by the researchers to collect data. The first instrument is the teachers' semi-structured interview. It consisted of six open-ended questions in which the responses were recorded on tapes and transcribed on the word document file. The students' semi-structured interview also contained six questions. The researcher followed the interview protocol and recorded the responses. For teachers, the conversations were steered using the English language only because all teachers were teaching English and having English language degrees. However, students had a choice on whether to interview in English or Arabic, their mother tongue, because some students were from the below-average and could not perform the interview in English. Later, the recordings were sent to a specialist to convert them to word document, and the responses in Arabic were also sent to translators to translate them into English. The responses were transcribed and stored in a word document file with a protected password on the researchers' computer and could not be reached by anyone, just by the researchers.

\subsection{Procedures}

The interviews took place during the 1st trimester of 2019/2020. Twelve teachers and 18 students from four different schools contributed to the conversations for over 15 days upon the availability of the teachers and the time of the researchers. The researchers guaranteed Al Ain office consent, established the schools' administrations' clearance as well as the teachers' and the students' approval to participate. Students' contributions in the interviews depended on students' voluntary basis, whether to participate or not. Each meeting took nearly 10 to 12 minutes to answer all the interview questions for both teachers and students. The interview recordings with all the papers were sent to a specialist to translate 
and transcribe them on the word document file. The researchers analyzed the data qualitatively using the hand analysis method and used inter-rater reliability to compare the results with an external validator using Cohen's Kappa, K, which was found to be $\mathrm{K}=0.77$, which the authors considered a substantial agreement between the two inter-raters. Then, the researchers discussed the results and the findings with the participants for results validation.

\subsection{Data Analysis}

The interviews were analyzed qualitatively by the researchers with the help of specialists. In both meetings, the teachers and the students responded to answer the two questions of the study. After careful analysis and comparisons of the sessions, the researchers produced the results of the two items of the research. The process of data analysis depended on the content analysis method where data was segmented, categorized into major themes, and reported. The researchers validated the results by showing and discussing them with the participants in focus groups.

\section{Findings}

The authors presented the research findings depending on the order of the questions. Question one findings come first and then followed by question two findings. The qualitative analysis depended on the content analysis method, where the hand analysis was developed to analyze the results. First, the interviews were recorded and then transcribed. The Arabic transcripts were translated into English and typed into a word document file. After that, the data were coded, segmented, and categorized into the major themes. Then inter-rater reliability was ensured to compare the topics and categories with another external validator who was considered an expert in qualitative data analysis. Kappa was found to be 0.77 in Table 2 which is considered substantial reliability as per Table 1. Table 1 shows the rating of Kappa.

Table 1: Interpretation of Kappa. Adopted from Viera and Garret (2005)

\begin{tabular}{cc}
\hline Kappa Agreement & Kappa Agreement \\
\hline$<0$ & Less than chance agreement \\
$0.01-0.20$ & Slight agreement \\
$0.21-0.40$ & Fair agreement \\
$0.41-0.60$ & Moderate agreement \\
$0.61-0.80$ & Substantial agreement \\
$0.81-0.99$ & Almost perfect agreement \\
\hline
\end{tabular}


Table 2: Cohen's Kappa Results

Symmetric Measures

\begin{tabular}{llllll}
\hline & Value & $\begin{array}{l}\text { Asymp. Std. } \\
\text { Errora }\end{array}$ & Approx. Tb & Approx. Sig. \\
\hline $\begin{array}{l}\text { Measure of Agreement Kappa } \\
\text { N of Valid Cases }\end{array}$ & .77 & .208 & 2.064 & .003 \\
\hline
\end{tabular}

a. Not assuming the null hypothesis.

b. Using the asymptotic standard error assuming the null hypothesis.

Finally, after reporting the results, they were validated by taking them back to the respondents to discuss with them whether their responses match the results. The findings of question one had two parts: first, the benefits of applying streaming as indicated by teachers, and then followed by the advantages of using splitting as signposted by students. There were four themes that appeared on the strengths as specified by teachers. The most common ones were streaming saves time, and planning for modified activities becomes easier; above-average students achieve better; streaming helps student centered-classes, and streaming gives equal opportunities for students to participate.

The first theme was related to planning and saving time. In streaming, teachers are no longer preparing for the three levels simultaneously; instead, they are planning just for one level of students. This way, planning becomes more comfortable, and teachers are no longer consuming most of their time preparing for the three levels. Teacher 1 and 7 talked about saving time. Teacher 7 indicated that "this year we started streaming, one advantage is timing. Streaming saves time in the class because all students are at the same proficiency level." Teacher 1 explained that "because the students level, now we can finish what we plan and prepare in the same period. Streaming saves time in the classroom." Teachers 2 and 5 remarked that streaming makes planning easier for differentiated education. Teacher 2 reflects "planning now is easier because we do not have more than one level in each class. The below-average students are all together, so one plan is enough for them and the same for the other two levels." Teacher 5 states that "planning used to take a lot of time at home, now it takes less time and less effort."

The second theme was related to above-average achievement. Nearly all teachers who contributed to the conversation talked about the advantages of streaming on above-average. Teacher 8 stated that "streaming benefits the aboveaverage the most because all the students are willing to participate. Their marks are getting better." Teacher 9 explained that "in order to compare the gains of the three levels, streaming helped the above-average students more than the others because they do not hinder classes, and do not interrupt classes like the low-level students." The aboveaverage students get the most benefit of streaming because classes are not interrupted. Moreover, teachers can pass the information quickly to the aboveaverage students in English without explaining in the mother tongue.

The third theme was that streaming drives classes to be more student-centered. Students can direct their learning, and teachers just monitor. Most of the time, 
students are learning based on their pace. Teacher 10 states that "in high ability classes, learning is more like student-centered; rather than teacher-centered. Students themselves are directing their learning." Teacher 4 stated that "streaming is changing the class to be more student-centered." All students are working on activities that make a challenge to them. So, streaming benefits all levels because it is more student-centered, especially in the above-average classes.

The fourth theme was that streaming has benefits on the below-average student, and the other levels, the average and the above-average. Teacher 4 indicated that "all students get equal opportunities to participate because they are in separate classes, and there is no dominance from the above-average over participation." The belowaverage students get an advantage from streaming in that they get rid of being shy. Now they can answer the questions as any other student in the same class. Teacher 12 stated that "because all the students are at the same level in the same classroom, students are encouraged to answer without being afraid that the answers are wrong."

Streaming has also benefited students according to students' interviews. Two significant themes appeared from the interviews; streaming increases students' interaction and participation, and streaming enhances students' grades. All students agreed that streaming develops students' engagement and cooperation, and streaming affects students' learning. The first theme was streaming helps students' interaction and engagement and promotes cooperation. Students 11, $12,14,17$, and 18 indicated that splitting enhances participation. Student 18 stated that "being in separate classes allows me to participate more." Student 17 remarked, "I am in the low level, and I became good and always participated." Student 14 states that "as an average student, I feel that I work better with students of my level, and we participate more." Student 11 said, "as an A level student, being with different classes increased our chances to participate more. Students 7 talked about increasing engagement. Student 7 states, "classrooms' interaction and student engagement increased.

The second theme was streaming enhances students' scores. Student 3 remarked "coursing helped me and gave me the motivation to move to high ability classes." Student 9 stated, "We should move to other classes if we get better, so I am working hard so that I can move." In general, students agreed that streaming affects students' learning. All students agreed that in some way, separation by streaming affects learning positively. Student 16 reflects, "Definitely, learning in this way affects results." Student 6 stated that "dividing students into different levels improves students' marks." Student 14 remarked, "Distinguished learning helps students progress. Distinction by streaming helps students to increase their marks." Students 18 noted, "Questions of the exams are easy, and we get good marks."

The findings of the 2nd question had two parts. The first part was the problems that the teachers indicated, followed by the weaknesses identified by students when applying to stream differentiated instruction. Four significant themes appeared regarding the challenges that teachers face when using "streaming" in differentiated classrooms. The most common issues of the disadvantages, as 
shown by the teachers, were the lack of motivation among average and belowaverage students, parents' refusal to stream their children by ability, low selfesteem among students, and finally increased behavioral issues in belowaverage classes.

Concerning the first theme, splitting increases the lack of motivation among the ordinary and the below-average. Teacher 1 remarked, "when streaming students, the below-average did not like to be labeled as below-average. They did not like to be separated from the average or above-average because they learn from them. Streaming prevents them from learning from other students." Teacher 12 stated that "the belowaverage classes are so weak and students barely answer questions. Students lack motivation because they do not have other ability students." Teacher 10 mentioned that "the below-average and even the average classes lack competition inside the classrooms, which affects their motivation." Streaming affected students' motivation among the below-average and average because they do not have other peers to encourage them to participate or to compete with since all the students in the same classrooms are within the same level.

Concerning the second theme, parents refused to stream their children by ability. Teacher 5 mentioned that "many parents refused to stream their children based on last years' marks, or just one placement test. It is unfair to separate students like this. Teacher 8 remarked that "many parents came to school, and they were able to shift their children one level up." Teachers said that parents declined to stream students, and many parents denied putting their children in low-ability classrooms. Teacher 1 stated that "many parents refused this streaming and transferred their children to private schools, where streaming is not applied."

The third theme is issues related to below-average classes. It has four subthemes, low self-esteem, increased behavioral problems, the use of mother tongue, and little classroom interaction was all significant complications happened because of streaming. Students of below-average showed low selfesteem. Teacher 8 agreed with 12 on that the below-average students showed no self-esteem. Teacher 12 stated that "the below-average students were not motivated by streaming, even their self-esteem was at the bottom." Most of the teachers talked about classroom communication in below-average classes. They agreed that the interaction was at the lowest limit. Teacher 10 said that "streaming prevented the low-level students from classroom collaboration because they often do not understand everything. They keep asking about everything, which sometimes hinders learning."

The fourth theme is streaming by ability in separate classes instead of having mixed-ability classrooms increases the misbehavior at schools. Most of the teachers said that streaming increased negative behavior, interruptions, and even misconduct. Teachers 4 and 6 ultimately agreed that streaming has adverse effects on below-average students. Teacher 6 stated that" the below-average classes misbehave compared to other courses. We did not use to have this issue in mixed-ability classrooms." Teacher 8 indicated that "below-average students always interrupt teachers. Fact, streaming does not help the low-level students to get better." Almost all teachers who contributed to the conversation indicated that they sometimes use their mother tongue to explain the tasks to students. While working on speaking tasks, the below-average uses Arabic, which is their mother tongue, and little 
English. Teacher 2 stated that "the use of Arabic is evident in the below-average classes. Teachers sometimes use their mother tongue to explain tasks, and students keep talking in Arabic."

The second part of the $2^{\text {nd }}$ question presents the disadvantages that the students recognized in streaming classes for differentiated instruction. Five themes appeared from students' discussions. The problems that the students face were that they do not like to be in separate classes. All grade levels should take the same book but not different books. Teachers do not take care of the belowaverage or even the average. So when the bad behavioral students are clustered together, the below-average feels embarrassed and inferior to other level groups.

The first theme was that students of the same class refused to be separated based on their ability. Student 1, 4, 15, and 18 explained their refusal to be separated from other students. Student 4 explained that "I do not like to be in this class and to learn like this. I want to be with the other students." Student 15 stated that "I hate this classification; I want to learn with other students.' Student 18 remarked that neither his father nor his mother liked him to be split from other students. They do not like him to be in the below-average courses. He stated, "My mother was angry with the school because of this classification. My dad declined to let me stay with the below-average students." Streaming leads to rejection, especially of the belowaverage students. They do not like labeling them as below-average learners.

The second theme was related to remarks mentioned by three students 2,8 , and 14 , which states that all students of the same class should take the same book, not different books. If teachers want to differentiate, they modify learning within the same level. Student 2 explained, "we take different books, why? We should take the same book." Student 8 stated, "I do not like our book; I want a book like the other levels." Student 14 remarked, "grade eight students have different books, why? We all should get the same book." When UAE started streaming, the students of the same grade are not taking the same book, which leads them to wonder why they receive different education to the other group of learners.

The third theme was that teachers take care only of the above-average students, and the below-average or the ordinary do not get the same attention from teachers. Student 13 stated, "I am an average student, but teachers do not take care of our level; I hear from the above-average that teachers give them much attention." Student 10 stated that "I am a below-average student, and I think our teachers are happier with the other levels." Below-average and average felt that students of above-average receive better education than they do, and teachers do not give them much attention as the above-average.

The fourth theme is related to behavioral issues, as indicated by students. Nearly most students talked about behavioral problems. Students of below-average still interrupt classes, and always misbehave in classes. Student 1 stated that "streaming helped students to behave negatively." Student 12 indicated that "coursing like this helped students to misbehave in classes." Student 15 mentioned that "the below-average students still act negatively and interrupt classes." Behavior appeared as a significant topic problem related to streaming. The below-average students 
keep making lots of behavioral issues that inhibit them from making many benefits from streaming.

The last theme was that all the below-average students, who contributed in the meetings, felt embarrassed because they were being labeled as below-average all the year. Student 3 said that "we started, and I still feel embarrassed. I want to move to the other level." Student 5 explained that "I always talk to my friends who are with me in my class, we do not feel happy. I feel embarrassed." The below-average students felt that they were inferior to the other two groups of students because they were labeled weak in English. Student 11 explained that "the other students of the other groups always say that they are better than us, they are with the clever students. I feel inferior; I do not like my class." Student 13 said that "splitting is not good. Some students feel that they are superior to others. Table 3 summarizes the themes of the two questions.

Table 3: Summary of Themes

\begin{tabular}{|l|l|}
\hline \multicolumn{1}{|c|}{ No } & \multicolumn{1}{c|}{ Theme } \\
\hline $\begin{array}{l}\text { Q1 first part } \\
\text { Advantages } \\
\text { from teachers' } \\
\text { views }\end{array}$ & $\begin{array}{l}\text { 1/streaming saves time, and planning for modified activities becomes } \\
\text { easier; } \\
\text { 2/above-average students achieve better; 3/streaming helps student } \\
\text { centered-classes, 4/streaming gives equal opportunities for students to } \\
\text { participate. }\end{array}$ \\
\hline $\begin{array}{l}\text { Q1 second part } \\
\text { Advantages } \\
\text { from students } \\
\text { views }\end{array}$ & $\begin{array}{l}1 / \text { streaming increases students' interaction participation, } \\
\text { 2/streaming enhances students' grades. }\end{array}$ \\
\hline $\begin{array}{l}\text { Q2 first part } \\
\text { disadvantages } \\
\text { indicated by } \\
\text { teachers }\end{array}$ & $\begin{array}{l}\text { 1/the lack of motivation among average and below-average students, } \\
\text { 2/parents' refusal to stream their children by ability, } \\
\text { 3/low self-esteem among students, } \\
\text { 4/increased behavioral issues in below-average classes. }\end{array}$ \\
\hline $\begin{array}{l}\text { Q2 second part } \\
\text { Disadvantages } \\
\text { indicated by } \\
\text { students }\end{array}$ & $\begin{array}{l}\text { 1/they do not like to be in separate classes. 2/all grade levels should } \\
\text { take the same book but not different books. } \\
\text { 3/teachers do not take care of the below-average or even the average. } \\
\text { 4/bad behavioral students are clustered together, } \\
\text { 5/the below-average feels embarrassed and inferior to other level } \\
\text { groups. }\end{array}$ \\
\hline
\end{tabular}

\section{Discussion}

Differentiated instruction by setting students into ability groups or streaming them into different class levels seems to improve students' learning. However, the implementation of streaming has many advantages and disadvantages based on teachers' and students' interviews. The study revealed numerous advantages and benefits to streaming. It is easier to prepare for streaming than to plan for a mixed-ability classroom because teachers are dealing with one plan per level. Teachers do not have to spend most of their time preparing for separate instruction to meet all students' standards in one classroom; instead, they expect one lesson plan per level, which saves time. The most benefit of streaming is for above-average students. Both teachers and students of all levels agreed that streaming is better for the above-average because they can read well, and learn faster than others. Besides, streaming helps classes to be more student-centered. 
The above-average students benefited the most from streaming probably because they worked without interruption from the other groups; they can act independently. Teachers are relaxed when explaining the lesson to them because they understand everything easier. This level of students, the high-achievers, can work faster than the other courses that gives them more time to anchor activities, which can be challenging to them. Streaming helps all levels to have equal opportunities to participate. In mixed-ability classrooms, it is the above-average who always dominates over the class. The below-average felt that they could involve and answer questions more when being streamed. When the belowaverage was in mixed-ability classrooms, it is the above-average and the ordinary who always engage, leaving the below-average with no chance.

The students' interviews also indicated several advantages of streaming. The above-average students were happier to be streamed because teachers are using English all the time, and not being interrupted by the below-average. Besides, the average and the above-average expressed that with streaming, the negative behavioral issues disappeared from their classes because the below-average were those who made the undesired behavioral issues. The above-average witnessed no bad behavioral issues indicating that streaming is better for their learning more than the mixed-ability classrooms. The below-average students expressed that with streaming, their scores became higher since they had different questions and different exams, although they are within the same grade level.

The finding of the study revealed that streaming had various disadvantages indicated by teachers' and students' interviews. The teachers signposted that splitting decreased motivation among the below-average and the average because they recognized that they were not equal to the above-average. The below-average felt that the other groups were getting much benefit compared to them because they receive different textbooks or even varied curriculum. Teachers, as well as students, thought that both students' interaction and engagement were not very high in streaming compared to differentiated instruction by setting. The minimal effect is on the below-average because both teachers and students agreed that dividing students by ability in separate classes would not help the below-average. Besides, many behavioral problems occurred in the below-average courses that they have not witnessed in mixed-ability classrooms. It is evident that teachers who teach the below-average encounter a lot of difficulties regarding interruption. Most of the below-average students do not understand the component of the lesson when teachers explain in English, so they keep interrupting teachers and talk in the mother tongue, which is Arabic. The teachers of the below-average use the native language to explain lessons in the target language. Students always interrupt teachers using Arabic language, which leads teachers to emphasize certain parts of the experience using their mother tongue.

Nobody liked to label him/her as a failure; the below-average and their parents refused to divide students in such a way that would leave their children embarrassed by being awkward. The below-average expressed that when being in below-average classes, it is a kind of classification that allows other children 
to label them as failures. The below-average revealed that they did not like to be in separate classes, and returning to mixed-ability classrooms would be much better because they would not feel embarrassed since all students are in the same class level. The findings of the students' interviews were similar to the results of teachers' meetings. The below-average feels embarrassed and their classes became worse than they were before.

Triangulating the teachers' perspectives regarding the advantages and disadvantages of streaming with students' perceptions can give a more robust insight on this type of distinction than taking one point of view, students' or the teachers' perspectives alone. Triangulation confirms the validity of the results. The results of the present study were inconsistent with Parson's (2013) results in that streaming has positive effects on above-average students and some adverse impacts on below-average students. Moreover, the two studies are similar in that splitting has an adverse social impact on students that the mixed-ability classrooms' students do not feel. Furthermore, the results of the current study were in line with Ritchard's (2014) study, in that parents refuse to stream their children by ability. The results of the current study were comparable to Mansor, Maniam, Hunt \& Nor (2016)'s conclusions in the advantages of streaming on the above-average students in that they achieved better when they cluster in separate courses. Moreover, the two studies' findings were equivalent in that streaming helps all learners to get higher marks than when they were in mixedability classrooms, and the above-average students got the most benefit as indicated by both studies.

\section{Conclusion}

In conclusion, the paper aimed to explore the advantages and the challenges that teachers and students face when applying differentiated instruction by streaming. All agree that students learn differently (Magableh \& Abdullah, 2020b). Different students learn in various methods depending on students' interests, readiness, and learning profiles. Two ways of classifying students are to follow in differentiated instruction: the first is the distinction by setting and the other by streaming. Streaming students by ability is the core of the current study. Like mixed-ability classrooms, streaming has many advantages and disadvantages. The most evident power agreed upon by all the respondents was streaming helps the above-average student more than the below-average or the average. However, the most common disadvantage of streaming was the interruption, and lack of interaction existed in the low-ability classrooms. With streaming, participation increases, and grades become higher. Like any method of teaching, streaming has many benefits and some challenges as indicated from both students' and teachers' sessions. The researchers recommend further investigations like a quantitative as well as a qualitative study to show which has more efficient on student learning, setting students in mixed-ability classrooms or streaming. The findings of the current study are limited due to the instrument, which only consists of interviews with both teachers and students. Moreover, the findings are limited due to the small sample size of teachers and students. A Larger number of participants and more instruments would get more reliable and valid results. 


\section{Conflict of interest:}

The authors witness that there are no conflicts of interest regarding the publication of this paper. The researchers received no direct funding for this research that might cause conflict.

\section{Acknowledgment}

The researchers would like to thank the board of education and the teachers involved for their support during the research. The acknowledgment extends to the school administrations and the students who are part of this study.

\section{References}

Anderson, K. (2007). Tips for teaching: Differentiating instruction to include all students. Preventing School Failure, 51(3), 49-54. https://doi.org/10.3200/psfl.51.3.49-54

Anstee, P. (2014). Differentiation Pocketbook. Management Pocketbooks.

Aysin, S., \& Serap, E. (2017). The effects of differentiated foreign language instruction on academic achievement and creativity of gifted students. Online Submission, 5(1), 276-287.

Bondie, R., Dahnke, C., \& Zusho, A. (2019). How does changing "one-size-fits-all" to differentiated instruction affect teaching? Review of Research in Education, 43(1), 336-362. https://doi.org/10.3102/0091732x18821130

Dendup, T., \& Onthanee, A. (2020). Effectiveness of cooperative learning on English communicative ability of $4^{\text {th }}$-grade students in Bhutan. International Journal of Instruction, 13(1) 255-266. https:/ / doi.org/10.29333/iji.2020.13117a

Gardner, H. (2018). Multiple approaches to understanding. In K. Illeris (Ed.) Contemporary theories of learning (pp. 129-138). London: Routledge. https://doi.org/10.4324/9781315147277-9

Hallam, S., \& Parsons, S. (2013). Prevalence of streaming in UK primary schools: Evidence from the Millennium Cohort Study. British Educational Research Journal, 39(3), 514-544.

Kauchak, D. (2013). Improving text simplification language modeling using unsimplified text data. In ACL (1) (pp. 1537-1546). Susan Hallam, Samantha Parsons. https:// doi.org/10.1080/01411926.2012.659721

Kotob, M., \& Abadi, M. (2019). The influence of differentiated instruction on academic achievement of students in mixed ability classrooms. International Linguistics Research, 2(2), 8-28. https://doi.org/10.30560/ilr.v2n2p8

Kumar, P. (2004). Ability grouping and academic achievement. Masalah Pendidikan Jilid, 27, 109-118.

Leblebicier, B. (2020). Learning through differentiated instruction: Action research in an academic class (Doctoral dissertation). Middle East Technical University.

Macqueen, S. (2008). Between-class achievement grouping for literacy and numeracy: Academic outcomes for primary students. In Proceedings of AARE 2008 Conference (pp. 112). Brisbane, QLD: University of Technology.

Magableh, I., \& Abdullah, A. (2019). The effect of differentiated instruction on developing students' reading comprehension achievement. International Journal of Management and Applied Science (IJMAS), 5(2), 48-53.

Magableh, I., \& Abdullah, A. (2020a). On the Effectiveness of Differentiated Instruction in the Enhancement of Jordanian Students' Overall Achievement. International Journal of Instruction, 13(2), 533-548. https:// doi.org/10.29333/iji.2020.13237a

Magableh, I. S. I., \& Abdullah, A. (2020b). Effectiveness of Differentiated Instruction on Primary School Students' English Reading Comprehension Achievement. 
International Journal of Learning, Teaching and Educational Research, 19(3), 20-35. https://doi.org/10.26803/ijlter.19.3.2

Mansor, A., Maniam, P., Hunt, M. C., \& Nor, M. (2016). Benefits and disadvantages of streaming practices to accommodate students by ability. Creative Education, 7(17), 2547-2558. https://doi.org/10.4236/ce.2016.717241

Pegram, M. E. (2019). Teachers' perceptions of implementing differentiated instruction for English Language learners.

Robb, L. (2008). Differentiating reading instruction: How to teach reading to meet the needs of each student. Education Review/Reseñas Educativas.

Richard, A. (2014). School streaming helps brightest pupils, but nobody else, say researchers. The Guardian, Thu 25 Sep 2014. Last modified Friday, March 2016.

Sisk, D. (2019). Differentiation: Using teaching strategies that facilitate learning in the inclusive classroom. In Cultivating Inclusive Practices in Contemporary K-12 Education (pp. 43-65). IGI Global.

Spina, N. (2019). 'Once upon a time': examining ability grouping and differentiation practices in cultures of evidence-based decision-making. Cambridge Journal of Education, 49(3), 329-348. https:// doi.org/10.1080/0305764x.2018.1533525

Tomlinson, C. (2014). The differentiated classroom: Responding to the needs of all learners. ASCD.

Tomlinson, C. (2015). Teaching for excellence in academically diverse classrooms. Society, 52(3), 203-209. https://doi.org/10.1007/s12115-015-9888-0

Tomlinson, C. (2017). How to differentiate instruction in an academically diverse classroom. ASCD.

Tomlinson, C., \& Imbeau, M. (2010). Leading and managing a differentiated classroom. ASCD.

Valiandes, S., \& Neophytou, L. (2018). Teachers' professional development for differentiated instruction in mixed-ability classrooms: investigating the impact of a development program on teachers' professional learning and students' achievement. Teacher Development, 22(1),

123-138. https:// doi.org/10.1080/13664530.2017.1338196

Viera, A. J., \& Garrett, J. M. (2005). Understanding interobserver agreement: The Kappa statistic. Fam med, 37(5), 360-363.

Weselby, C. (2014). What is differentiated instruction? Examples of how to differentiate instruction in the classroom. Teaching Strategies.

Wesley-Nero, S. (2007). A study of the effectiveness of an alternative licensure program for urban elementary teachers of English Language learners (Ph.D. Dissertation). George Mason University.

Westwood, P. (2018). Inclusive and adaptive teaching: Meeting the challenge of diversity in the classroom. Routledge. 